\title{
Fra Safety-I til Safety-II: Mot nye perspektiver på pasientsikkerhet i selvmordsforebygging
}

\author{
AV SIV HILDE BERG
}

\section{Sammendrag}

Sentralt for resiliens i helsetjenesten er Safety-II-perspektivet. I et Safety-II-perspektiv anses tilpasninger som sentralt for å skape trygge pasientforløp for den enkelte pasient. Forfatteren argumenterer for at resiliens i helsetjenesten gir nyttige perspektiver til suicidfeltet. I et Safety-I-perspektiv forebygges selvmord ved å sikre at alle ansatte følger prosedyrer og korrigerer svikt. Mens Safety-I-tilnærmingen kan gi gode resultater i en klinisk praksis hvor det er kunnskapsgrunnlag for at den enkelte prosedyren gir gode utfall for pasienten, vil ikke denne tilnærmingen være tilstrekkelig i en praksis kjennetegnet av usikkerhet relatert til hva som virker, og hvor prosedyren ofte tilpasses for å imøtekomme varierende krav i pasientbehandlingen. I et Safety-II-perspektiv forstås sikkerhet som systemets evne til å oppnå suksess under varierende omstendigheter. Forskning på resiliens i helsetjenesten og Safety-II-perspektivet innen selvmordsforebygging er i startfasen. Studiene gir innsikt i at et Safety-II-perspektiv på sikkerhet i selvmordsforebygging innebærer å innlemme det individtilpassede og relasionelle i pasientsikkerhetsarbeidet. Et Safety-II-perspektiv innebærer også en endring på regulerings- og tilsynsnivå fra å plassere skylden for pasientselvmordet på det enkelte helsepersonell og manglende selvmordsrisikovurderinger, til å forstå og anerkjenne kompleksiteten helsepersonell til daglig står overfor.

\begin{abstract}
Safety-II is a core concept in resilient healthcare. The Safety-II approach perceives adaptation as the central tenet to create safe care for each patient. The author argues that resilient healthcare provides useful perspectives to the suicide field. From a Safety-I perspective, suicide is prevented by ensuring that all healthcare professionals follow procedures and correct failures. While the Safety-I approach can give successful results in clinical practices with predictable outcomes of the implemented safety measures, this approach has some limitations when applied to practices in which the risk is not completely understood. In such practices, deviations from standards may be necessary to respond to varying conditions, e.g., patient heterogeneity and changing needs. Safety-II is the presence of an ability that enables things to go right across varying conditions. Research on resilient healthcare and the Safety-II-perspective in suicide prevention is in its early beginning. The studies provides insight that a Safety-II perspective in clinical suicide prevention involves integrating individualised and relational components in the patient safety work. At the level of regulatory authorities and health supervisions, a Safety-II perspective involves moving away from perceiving healthcare professionals and improper suicide risk assessments as the main cause of the patient suicides, to acknowledge the complexity clinicians face when making the decisions and adapting treatment to individuals.
\end{abstract}




\section{Innledning}

Hva vi vektlegger når vi prater om pasientsikkerhet vil være avhengig av hvilket perspektiv vi inntar på sikkerhet (Haavik, 2014). Slik status på kunnskapsfeltet er per i dag vet vi ikke nok om hvordan vi skal forstå pasientsikkerhet i psykisk helse (Brickell et al., 2009). Det finnes svært få fagfellevurderte empiriske studier som diskuterer perspektiver på pasientsikkerhet og suicidal atferd, til tross for at selvmordsforebygging i sengepost er en anerkient og sentral del av pasientsikkerhetsarbeidet (Thibaut et al., 2019).

Noen få studier beskriver perspektiver på pasientsikkerhet i mental helse som står i motsetningsforhold til hverandre. I en kvalitativ studie av psykiatriske sengeposter i England fant Curtis et al. (2013) en konflikt mellom «teknisk sikkerhet» i form av fysisk infrastruktur, og sikkerheten som ble skapt giennom terapeutiske tilnærminger. Curtis et al. (2013) fant at det å fysisk skjerme eller låse dørene skapte en psykologisk avstand til ansvaret helsepersonell hadde i å håndtere pasientens risiko. I en etnografisk studie av australske psykiatriske sengeposter fant Plumb (2013) at den «disiplinerende sikkerheten», det vi si tiltakene som rettes mot kontroll og styring av risiko, sto i konflikt med sikkerheten som ble skapt i de persontilpassede aktivitetene. Helsepersonell søkte etter å dempe følelsen av usikkerhet ved å lene seg til dokumenteringen, skjemaene og reglene, fordi det beskyttet dem for personlig risiko om noe skulle gå galt, selv om det gikk på bekostning av nærheten til pasienten. Men en kan, ifølge Plumb (2013), ikke eliminere usikkerhet verken med bygninger eller skjemaer. Usikkerhet er et kjennetegn ved det å arbeide med mennesker i psykisk helse.

Litteraturen gir innsikt $\mathrm{i}$ at pasientsikkerhet $\mathrm{i}$ konteksten av psykisk helse ikke bare kan forstås som det å fysisk beskytte pasienten fra å skade seg. Det handler også om å håndtere usikkerhet og ulike behov i den personlige kontakten med pasientene. Suicidalitetsfeltet har vært preget av en debatt som reflekterer dualiteten mellom systematiske og tekniske perspektiver på sikkerhet, og relasionelle og terapeutiske perspektiver på sikkerhet (Large et al., 2011; Undrill, 2007). I klinisk praksis beskrives tilpasninger av arbeidet for å være sensitiv til konteksten og den enkelte pasient i det selvmordsforebyggende arbeidet som står i kontrast til den økende standardiseringen av praksis (Waern et al., 2016; Østlie et al., 2018; Hagen et al., 2017; Berg et al., 2020b). Disse komplekse dynamiske prosessene er i fokus i forskningsdisiplinen resiliens i helsetjenesten.

Formålet med denne litteraturgiennomgangen er å presentere et sikkerhetsteoretisk perspektiv for pasienter i selvmordskrise hentet fra resiliens i helsetienesten. Problemstillingen for artikkelen er: Hvordan kan vi forstå selvmordsforebygging i perspektiver fra resiliens $i$ helsetienesten? Artikkelen gir en innforing i resiliens i helsetjenesten og en giennomgang av litte- 


\section{En kan ikke eliminere usikkerhet verken med bygninger eller skjemaer. Usikkerhet er et kjennetegn ved det å arbeide med mennesker i psykisk helse.}

ratur som anvender perspektiver fra resiliens i helsetienesten i selvmordsforebygging. Litteraturstudien inkluderer studier fra min doktorgradsavhandling Safe clinical practice for patiens hospitalised in mental healthcare during a suicidal crisis (Berg, 2020).

\section{Resiliens i helsetjenesten}

Det finnes ulike forståelser av begrepet resiliens, slik som psykologisk resiliens, resiliens i økologien og resiliens i kritisk infrastruktur, som fokuserer på å bygge opp igien samfunn etter en naturkatastrofe eller krise (Turenne et al., 2019). Resiliens i helsetjenesten henter elementer fra disse tre forståelsene av resiliens, med hovedvekt på et systemperspektiv (Wiig et al., 2020). Det finnes per i dag ikke et norsk ord for resiliens. Resiliens i helsetjenesten er ifølge Wiig med kollegaer (2020) kapasiteten til å tilpasse seg til utfordringer og endringer på ulike systemnivåer for å opprettholde høy kvalitet i tjenesten.

Fra 2012 har studier av resiliens i helsetjenesten hatt stor vekst (Ellis et al., 2019). De teoretiske modellene og metodene er i utvikling, samtidig som mengden empiriske studier vokser. Resiliens i helsetjenesten benytter derfor ulike begreper og teorier med ulik grad av operasjonaliserbarhet og empirisk støtte (Berg et al., 2018; Iflaifel et al., 2020). På klinisk nivå er tilpasninger rettet mot alt fra prosedyrer, dokumentasjonskrav, pasienters ulike behov, og til å forstå og respondere på uforutsette og utydelige hendelser (Berg \& Aase, 2019). På systemnivå er evnen til å respondere på det som skjer, forutse mulige problemer, fleksibelt oppfatte problemer, og lære fra erfaring ansett som sentrale resiliente trekk (Hollnagel, 2oog).

Den grunnleggende antakelsen for resiliens i helsetjenesten er at helsetjenesten er et komplekst adaptivt system (Braithwaite et al., 2013). Psykiske helsetjenester anses som komplekse adaptive systemer fordi pasienter, ulike grupper av helsepersonell og pårørende er i interaksjon med hverandre og påvirker praksis. Det er av og til usikkert hva som virker og hvorfor, og behandlingen består ofte av en rekke tiltak som er tilpasset den enkelte pasients behov og ulike krav om endringer fra myndighetsnivå (Ellis et al., 2017).

Et kjernebegrep for resiliens i helsetjenesten er Safety-II-perspektivet; sikkerhet må forstås ut ifra systemets evne til å oppnå suksess under varierende omstendigheter (Hollnagel, 2014). Safety-II er ikke et veldefinert begrep, og er å anse som en samling av ideer snarere enn en modell (Berg et al., 2018). Ifølge Hollnagel (2014) er den tradisjonelle forståelsen av pasientsikkerhet definert som fraværet av uønskede hendelser. Fokuset er på det som går galt og sikkerhetsarbeidet rettes mot håndtering av uønskede hendelser. Hollnagel omtaler den tradisjonelle tilnærmingen som «Safety-I»-tilnærming til sikkerhet. I Safety-I-tilnærmingen handler pasientsikkerhet ofte om å sette inn en rekke enkelttiltak og barrierer for å forhindre skader. Et eksempel på Safety-I-tilnærming er den nasjonale pasientsikkerhetskampanjen, som involverte forebygging av selvmord i psykiatriske sengeposter. Suksess i Safety-I-tilnærmingen forutsetter at man har kunnskap om at man vet at enkelttiltakene vil gi reduksjon av skade (Hollnagel, 2014). I komplekse adaptive systemer er det derimot vanskelig å vite helt eksakt hva som virker og hvordan, fordi suksessfulle utfall ofte er et resultat av tilpasninger i klinisk praksis. Det kan gi uforutsigbare og variable utfall av tiltak som iverksettes i praksis (Braithwaite et al., 2013). Safety-II-perspektivet flytter fokus fra å utelukkende lære av svikt i fortiden, til å lære av systemets tilpasningsevne i møte med varierende krav (Hollnagel, 2014). Ofte er det avvik mellom klinisk praksis og retningslinjer og prosedyrer. I et resiliensperspektiv er denne innsikten i seg selv verdifull, fordi det gir en mulighet til å forstå sikkerhet i klinisk praksis og tilpasse retningslinjer deretter (Hollnagel, 2014). 
arbeidet med suicidale pasienter i sengepost intervjuet individuelt og/eller i fokusgrupper. Safety-II kunne forstås som bruk av ekspertise i oppfattelsen av suicidalitet, individtilpassing av behandlingen og bruk av formelle og uformelle støttesystemer for å håndtere personlig usikkerhet i det selvmordsforebyggende arbeidet. Et eksempel på Safety-II-tilnærming til selvmordsrisikovurdering er bruk av en rekke strategier for å oke situasjonsforståelsen av hva de sto ovenfor, slik som å tolke både verbal og nonverbal atferd, bruke en rekke informasjonskilder og drøfte vurderingen med kollegaer og med pasienten. Flere helsepersonell la også sjekklister til side i samtaler med pasienten for å skape tillitsfulle bånd. Helsepersonell erfarte at trygghet ble skapt i den individualiserte behandlingen rettet mot den enkelte pasients underliggende problemer og den enkeltes beskyttelsesbehov. Men hva som var sikkert nivå av beskyttelse for den enkelte pasient var i konstant endring og besto av en rekke kliniske overveielser mellom flere ulemper i pasientbehandlingen, både i frykt for å underbeskytte og overbeskytte pasienten (Berg et al., 202ob). For at observasjon av selvmordsfare skulle være trygt for den enkelte, ble derfor flere hensyn veiet opp mot hverandre: ikke slippe pasienten av syne, ivaretakelse av pasientens verdighet og ivaretakelse av pasientens behov for tilknytning. Et eksempel på Safety-II-tilnærming til observasion av selvmordsfare, er sykepleieren som får pasienten på intervallobservasjon ut av pasientrommet og inn på skjermingsstuen. Det å åpne døren og kun sjekke om pasienten var i live hvert femte minutt, var ikke noe han vurderte signaliserte verdighet, mens i stuen var han likemann uten at han slapp pasienten av syne (Berg et al., 202ob).

Ved å analysere studiene på tvers, fant Berg (2020) en rekke kjennetegn ved sikker klinisk praksis for pasienter innlagt i selvmordskrise, som kjennetegner komplekse adaptive systemer. Suicidale pasienter er ikke en homogen gruppe; det er individer med svært ulike årsaker til suicidal atferd, med ulike behandlingsbehov, beskyttelsesbehov, og ulik kapasitet til å sette ord på egne behov og selvmordstanker. Behandling og beskyttelse tilpasses for å være sensitiv til individet og konteksten, noe som vanskeliggiør standardisering av praksis. Kompleksiteten kjennetegnes også i stor grad av at beslutninger om selvmordsrisiko tas under høy grad av usikkerhet. Beslutninger om
.

\section{I et Safety-II-perspektiv er pasientens subjektive erfaringer, følelse av trygghet og imøte- kommelse av grunnleggende psykologiske behov sentralt for suicidale pasienters perspektiv på pasientsikkerhet.}

selvmordsrisiko er en «sensemaking»-prosess. Sensemaking er meningsdannelsen vi igangsetter når vi prøver å forstå nye, uventede og utydelige hendelser, og forsøker å skape mening i møte med usikkerhet og kjennetegner beslutningstaking i komplekse systemer (Berg \& Aase, 2019; Klein et al., 2006). Praksis besto også av en rekke kliniske overveielser, «trade-offs», som kjennetegner beslutningstaking i komplekse systemer, nettopp fordi ulike verdier står i motsetningsforhold til hverandre, og det ikke finnes et fasitsvar (Wears et al., 2015). Kompleksitet relateres også til sikkerhet som skapes i relasjonelle prosesser hvor tillitt og pasientens opplevelse av sikkerhet står sentralt. Resiliente psykiske helsetjenester er avhengig av å ha støttesystemer som ivaretar helsepersonellet for å håndtere usikkerhet i arbeidet, og klare å være nær pasientens sårbarhet (Berg, 2020). For å styrke systemets evne til å oppnå suksess under varierende omstendigheter (Safety-II) må det selvmordsforebyggende arbeidet romme denne kompleksiteten.

\section{Poliklinisk setting}

I en «editorial» fra de to ledende forskningssentrene innen pasientsikkerhet og selvmordsforskning ved Universitetet i Manchester, ble Safety-II lansert som et «nytt paradigme» i selvmordsforskningen (Quinlivan et al., 2020). Manchester-miljøet inkluderer forskningsteamet bak «National Confidential Inquiery Into Suicide and Safety in Mental Health», som har systematisk gransket selvmordshendelser i helse- 
tjenesten i Storbritannia i over 20 år. Fremover skal de benytte et integrativt rammeverk som både tar for seg kunnskap om årsaker til selvmord og feil i helsetjenesten, og de skal hente inn kunnskap om prosesser, dynamikk og kompleksitet i den virkelige kliniske hverdagen. De lener seg på implementeringsforskning for å kunne få denne kunnskapen omsatt til praksis.

Studien av Littlewood et al. (2019) er den forste publiserte empiriske studien i et resiliensperspektiv fra Manchester-miliøet. Studien har studert helsepersonells perspektiver på hva som er god praksis i psykiske helsetjenester for suicidale pasienter. Studien analyserte kvalitative data fra fritekstfelt som var samlet inn via spørreskiemaer, og inkluderte perspektiver fra 62 helsepersonell med ulik profesjonell bakgrunn. Studien finner forhold som helsepersonell relaterer til god praksis (Safety-II): betydningen av å skape tryggere omgivelser (bruk av trent personell på observasjon, kriseplaner, håndtering av medikamenter, vurdering av mental tilstand for permisjon), rask tilgang til skreddersydde tienester, sømlose overføringer i helsetjenesten, betydningen av samarbeidsrelasion med pasienten og pårørende, og ha et team av helsepersonell som har tilstrekkelig med ekspertise, ressurser og støtte (Littlewood et al., 2019).

Iun et al. (2019) sammenliknet en Safety-I- versus Safety-II-tilnærming til selvmordsforebygging for å forstå hvordan kommunehelsetjenesten i England oppdaget og behandlet selvmordsrisiko. For å forstå praksis i et Safety-II-perspektiv ble 20 helsepersonell intervjuet om hvordan de erfarte suksessfull oppdagelse av selvmordsrisiko og respons. Studien fant at beslutninger om selvmordsrisiko var en kompleks beslutningstakingsprosess. Beslutninger ble tatt under høy grad av usikkerhet og helsepersonell sto i konstante «trade-offs» mellom juridiske krav om forsvarlighet, pasientens krav og personlige og økonomiske ressurser. Sikkerhet for den suicidale pasienten var noe som ble skapt i kliniske overveielser for hver pasient. Jun et al. (2019) fant betydningen av sosial støtte for at helsepersonell skulle kunne yte suksessfullt $i$ arbeidet med suicidale pasienter.

\section{Regulerings- og tilsynsnivå}

På regulerings- og tilsynsnivå har litteratur om selvmordsforebygging i perspektiv blitt omtalt i to litteraturstudier (Svendsson, 2021; Turner et al., 2020) og en dokumentanalyse av granskingsrapporter (Fröding et al., 2020). Litteraturen beskriver hovedsakelig tilstedeværelsen av et Safety-I-perspektiv og hvilke negative konsekvenser dette har for fagfeltet. Litteraturen indikerer at et Safety-II-perspektiv innebærer å anerkjenne behovet for tilpasninger i det selvmordsforebyggende arbeidet, og utvikle systemer for å lære mer om hva som virker i hverdagspraksis og hvorfor.

\section{Gransking av selvmordshendelser}

I en giennomgang av tilsynsrapporter fra selvmordshendelser i Sverige giennom 13 år, fant Fröding et al. (2021) at det overdrevne fokuset på Safety-I ga begrensninger i hvorvidt de lærte av selvmordshendelsene. Tilsynet hadde utelukkende satt søkelys på rutinesvikt i helsepersonell-pasientkontakten, hvor den vanligste identifiserte svikten var manglende selvmordsrisikovurderinger. Tiltak hadde hovedsakelig blitt rettet mot å lage nye rutiner, eller å oppdatere eksisterende rutiner. Tilsynet hadde ikke undersøkt forhold til at rutinene ikke ble fulgt, eller hvorvidt rutinene var giennomførbare i praksis. Læring på tvers av avdelinger var svært begrenset. Fröding et al. (2021) argumenterer for å designe bedre læringssystemer for å lære av suksessfulle behandlingsforløp.

I en litteraturstudie argumenterer Turner et al. (2020) for at Safety-I-perspektivet har fort til en rekke negative konsekvenser for fagfeltet. De påpeker at det er en overdreven tro på at selvmordsrisikovurderinger kan predikere selvmord, selv om vi har evidens på at vi ikke kan predikere selvmord i klinisk arbeid ved å bruke risikofaktorer eller instrumenter som deler pasientene inn i høy- og lavrisikogrupper. I gransking av selvmordshendelser i helsetienesten verden over med bruk av kjerneårsaksanalyser (eksempelvis feiltre- og hendelsesanalyser), har det ofte blitt konkludert med at selvmordet skyldes fraværet av risikovurderinger. Det giør helsepersonellet til et sekundært offer for selvmordet. Frykten for straff og å giøre feil har skapt en fryktkultur som disiplinerer helsepersonell til å prioritere dokumentasjonskrav (Turner et al., 2020). Ifølge Turner et al. (2020) går dette på bekostning av fokuset på helsepersonells ekspertise og den sikkerheten som skapes i de relasjonelle og terapeutiske prosessene. Turner et al. (2020) diskuterer svakhetene ved et Safety-I-perspektiv i selvmordsforebygging; når læring har et retrospektivt 



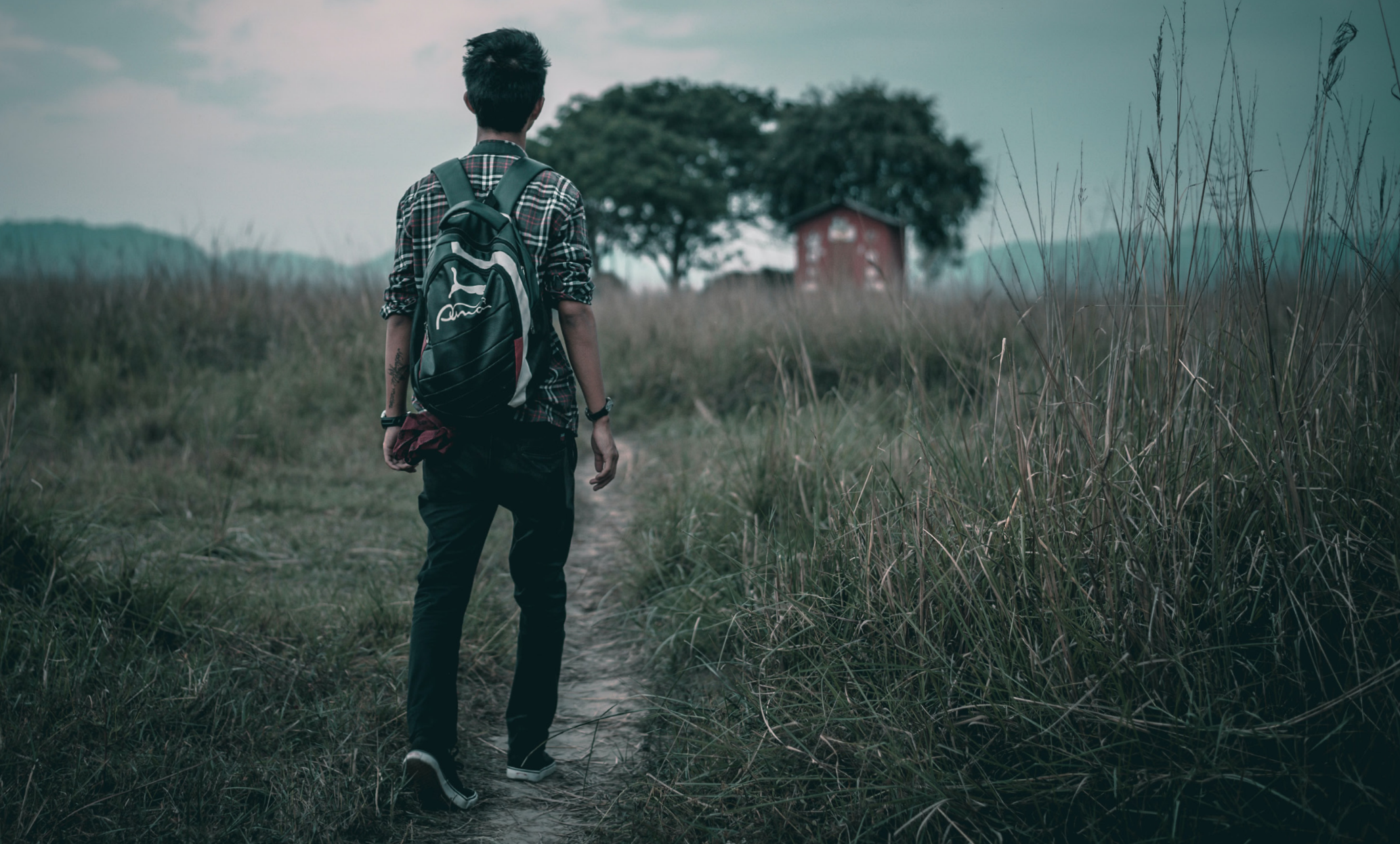

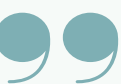

Studiene antyder at selvmordsrisikovurderinger, slik de utføres i praksis, involverer mer enn hva som kan rommes av en sjekkliste; det involverer ekspertise, erfaringsbaserte mentale modeller, intuisjon og relasjon, og samarbeid i team og med pasienten.

Studiene antyder at selvmordsrisikovurderinger, slik de utfores i praksis, involverer mer enn hva som kan rommes av en sjekkliste; det involverer ekspertise, erfaringsbaserte mentale modeller, intuisjon og relasion, og samarbeid i team og med pasienten (Berg et al., 2020b; June et al., 2019). Sett i et Safety-II-perspektiv involverer selvmordsrisikovurderinger både oppfattelsen av kompleks informasion og motet med mennesker med psykisk smerte. Safety-II-perspektivet resonnerer med studier som finner at helsepersonell bruker erfaringsbasert og emosionell kompetanse i vurderinger av selvmordsrisiko (Waern et al., 2016; Hagen et al., 2017; Ostlie et al., 2017) og helhetlige evidensbaserte tilnærminger til behandling av selvmordsrisiko (f.eks. CAMS og DBT), som innlemmer vurdering med terapien (Jobes, 2012; Linehan et al., 2006). En viktig begrensning er at disse studiene kun beskriver prosesser i klinisk praksis. Ingen av studiene knytter disse prosessene til utfallsmål og til effektiv oppdagelse av selvmordsrisiko. Det er behov for studier av hvordan klinisk beslutningstaking vedrørende selvmordsrisiko utføres i praksis, som også knytter ulike prosessmål til utfallsmål (pasienterfaringer, selvmordshendelser).

I et Safety-II-perspektiv anses beskyttelse av individer i selvmordsfare som en dynamisk og relasjonell praksis med kontante individtilpasninger og 
kliniske overveielser (trade-offs) mellom ulike verdier og krav, som ofte står i motsetning til hverandre (Jun et al., 2019; Berg et al., 2020b). Dette står i kontrast til den nåværende forståelsen av observasion av selvmordsfare som et statisk sikkerhetstiltak hvor det skal folges ulike tidsintervaller for sjekkpunkter av pasienten, enten ved intervallobservasion eller kontinuerlig observasion. Safety-II-perspektivet resonnerer med studier som finner at observasion er en terapeutisk intervensjon, som både kan bidra til å fremme håp, men i fraværet av relasjonen til helsepersonell kan fore til negative konsekvenser for pasienten (Cardell \& Pitula, 1999; Cutcliffe et al., 2007). Safety-II-perspektivet resonnerer også med Vråle og Steens (2005) studie som finner at observasion er i stadig bevegelse mellom å kontrollere at pasienten ikke skader seg og å skape relasion. Det finnes ingen randomiserte kontrollerte studier av observasion av pasienter i selvmordsfare, og vi har ikke evidens på effekten av observasion (Chu, 2016). Kvalitative studier fra klinisk praksis om hvordan observasion virker har derfor stor verdi. Samtidig poengterer Hollnagel (2014) at tilpasninger også kan ha negative utfall i praksis, og det er behov for studier som knytter prosess til utfallsmål (pasienterfaringer, selvmordshendelser).

Dokumentgiennomgang og litteraturstudier av regulerings- og tilsynsnivå gir innsikt i en begrenset nytteverdi av kjerneårsaksanalyser relatert til selvmordshendelser fordi fokus rettes utelukkende mot helsepersonell som årsak til svikt (Turner et al., 2020; Fröding et al., 2019; Svensson, 2021). Hvert år dør om lag 25 personer av selvmord mens de er innlagt i psykisk helsevern i Norge (Walby et al., 2018). Vi har ingen metoder for å predikere hvilke pasienter som kommer til å ta livet sitt i sengepost og vi vet ikke eksakt hva som skal til for å forhindre at den enkelte pasienten tar livet sitt (Belsher et al., 2019; Large et al., 2011; Turecki \& Brent, 2016). Samtidig viser studiene at regulering og tilsyn av helsepersonellet fortsatt anses som kjerneårsaken til svikt ved pasientselvmord (Turner et al., 2020; Fröding et al., 2019; Svensson, 2021). Det er et sterkt behov for å flytte fokus fra å skylde på helsepersonellet i den spisse enden i systemet. En bevegelse fra Safety-I- til Safety-IIperspektiv fordrer nye granskingsmodeller og systemer for læring i det selvmordsforebyggende arbeidet. Det er behov for modeller og tilnærminger som vurderer bakenforliggende årsaker til svikt i hele helsetjenesten og som søker etter å forstå gode utfall i hverdagspraksis.

\section{Konklusjon}

Denne litteraturgiennomgangen har gitt en giennomgang av forskningsspørsmålet: Hvordan kan vi forstå selvmordsforebygging i perspektiver fra resiliens i helsetienesten? Litteraturgiennomgangen illustrerer at forskning på selvmordsforebygging i perspektiver fra resiliens i helsetjenesten står ved startstreken, med noen få bidrag fra Norge, Storbritannia og Australia. Kunnskapsgrunnlaget er for svakt for å gi implikasioner for klinisk praksis. Det er behov for flere empiriske studier, i flere kliniske settinger, ledelsesnivået, regulerings- og tilsynsnivået, og pårørendes perspektiver. Det er også behov for å undersøke resiliens i psykiske helsetjenester i kommunen, og i settinger som omfatter aldersgruppene barn, ungdom og eldre.

Hvordan vi tilnærmer oss sikkerhet er avhengig av ulike perspektiver på sikkerhet. Ved å se selvmordsforebygging i perspektiver fra resiliens i helsetjenesten rettes blikket mot kompleksitet og de tilpasninger som giøres til den enkelte pasient og til den kliniske hverdagen. Perspektiver fra resiliens i helsetjenesten gir også et rasjonale for at pasientsikkerhet må bevege seg videre fra et Safety-I-perspektiv med et utelukkende fokus på svikt i helsepersonell-pasientkontakten, mot et Safety-II-perspektiv som anerkjenner kompleksitet og lærer av prosesser som bidrar til at helsetjenesten er i stand til å håndtere utfordringer og endringer i klinisk praksis. Et Safety-II-perspektiv vil ha implikasioner for hvordan vi tilnærmer oss nasjonale pasientsikkerhetsstrategier, nullvision for selvmord, og implementering av nye nasionale faglige retningslinjer.

\section{Takk til}

Fagmiliøet ved SHARE - Center for Resilience in Healthcare, og mine samarbeidspartnere Karina Aase, Fredrik A. Walby og Kristine Rørtveit, som har bidratt i utviklingen av perspektiver på resiliens i helsetjenesten og applikeringen av disse i psykiske helsetjenester. 


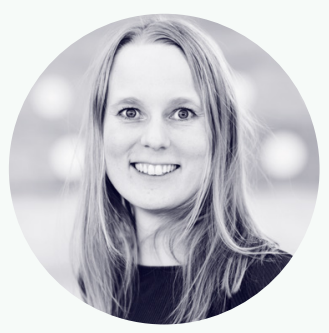

\section{SIV HILDE BERG}

er PhD og klinisk psykolog med en tverrfaglig bakgrunn innen samfunnssikkerhet. Hennes forskningsfelt er resiliens i helsetjenesten, sikkerhetsteori og selvmordsforebygging, samt bruk av pasienterfaringer for å få kunnskap om helsetjenesten. Berg har også arbeidet klinisk med selvmordsforebygging i spesialisthelsetjenesten.

\section{Referanser:}

Belsher, B. E., Smolenski, D. J., Pruitt, L. D., Bush, N. E., Beech, E. H., Workman, D. E., . . Skopp, N. A. (2019). Prediction Models for Suicide Attempts and Deaths: A Systematic Review and Simulation. JAMA Psychiatry, 76(6), 642-651.

Berg, S. H. (2020). Safe clinical practice for patients hospitalised in mental healthcare during a suicidal crisis. (Doktorgradsavhandling, Det helsevitenskaplege fakultet). Stavanger: Universitetet i Stavanger. Hentet fra https://hdl.handle.net/11250/2675498.

Berg, S. H., \& Aase, K. (2019). Resilient Characteristics as Described in Empirical Studies on Health Care. I: S. Wiig \& B. Fahlbruch (Red.). Exploring Resilience. A Scientific Journey from Practice to Theory (s. 79-87). Springer, Cham.

Berg, S. H., Akerjordet, K., Ekstedt, M. \& Aase, K. (2018). Methodological strategies in resilient health care studies: An integrative review. Safety Science, 110, 300-312.

Berg, S. H., Rørtveit, K., \& Aase, K. (2017a). Suicidal patients' experiences regarding their safety during psychiatric in-patient care: a systematic review of qualitative studies.

BMC Health Services Research, 17(1), 73.

Berg, S. H., Rørtveit, K., Walby, F., \& Aase, K. (2017b). Safe clinical practice for patients hospitalised in a suicidal crisis: a study protocol for a qualitative case study. BMJ Open, 7(1), e012874.
Berg, S. H., Rørtveit, K., Walby, F. A., \& Aase, K. (2020a). Safe clinical practice for patients hospitalised in mental health wards during a suicidal crisis: qualitative study of patient experiences. BMJ Open, 10(11), e040088.

Berg, S. H., Rørtveit, K., Walby, A. F., \& Aaase, K. (2020b). Adaptive capacities for safe clinical practice for patients hospitalised during a suicidal crisis: A qualitative study. BMC Psychiatry, 20(1), 316.

Braithwaite, J., Clay-Williams, R., Nugus, P., \& Plumb, J. (2013). Health Care as a Complex Adaptive System. I: E. Hollnagel, J. Braithwaite \& R. L. Wears (Red.). Resilient Health Care (Vol. 1). England: Ashgate Studies in Resilience Engineering.

Brickell, T. A., Nicholls, T. L., Procyshyn, R. M., McLean, C., Dempster, R. J., Lavoie, J. A. A., . . Wang, E. (2009). Patient safety in mental health. Edmonton, Alberta: Canadian Patient Safety Institute and Ontario Hospital Association.

Cardell, R., \& Pitula, C. R. (1999). Suicidal inpatients' perceptions of therapeutic and nontherapeutic aspects of constant observation. Psychiatric Services, 50(8), 1066-1070.

Chu, S. (2016). Special observations in the care of psychiatric inpatients: a review of the literature and developments in practice. ARC Journal of Psychiatry, 1(1), 21-31.

Curtis, S., Gesler, W., Wood, V., Spencer, I., Mason, J., \& Close, H. (2013). Compassionate containment? Balancing technical safety and therapy in the design of psychiatric wards. Social Science \& Medicine, $97,201-209$

Cutcliffe, J. R., Stevenson, C., Jackoson, S., \& Smith, P. (2006) A modified grounded theory study of how psychiatric nurses work with suicidal people. Int J Nurs Stud, 43(7), 791-802.

Ellis, L. A., Churruca, K., \& Braithwaite, J. (2017). Mental health services conceptualised as complex adaptive systems: what can be learned? International Journal of Mental Health Systems, 11(1), 43.

Ellis, L. A., Churruca, K., Clay-Williams, R., Pomare, C., Austin, E. E., Long, J. C., ... Braithwaite, J. (2019). Patterns of resilience: A scoping review and bibliometric analysis of resilient health care. Safety Science, $118,241-257$

Fröding, E.,Gäre, B., Westrin, Å., \& Ros, A. (2021) Suicide as an incident of severe patient harm: a retrospective cohort study of investigations after suicide in Swedish healthcare in a 13-year perspective. BMJ Open, 11(3), e044068.

Haavik, T. K. (2014). On the ontology of safety. Safety Science, 67, 37-43.

Hagen, J., Knizek, B. L., \& Hjelmeland, H. (2017). Mental Health Nurses' Experiences of Caring for Suicidal Patients in Psychiatric Wards: An Emotional Endeavor. Archives of Psychiatric Nursing, 31(1), 31-37.

Hollnagel, E. (2009) The Four Cornerstones of Resilience Engineering. I: C. P. Nemeth, E. Hollnagel \& S. W. A. Dekker. (Red.), Resilience Engineering Perspectives, Volume 2: Preparation and Restoration (s. 117-133). Surrey: Ashgate.

Hollnagel, E. (2014). Safety-I and Safety-II: The Past and Future of Safety Management. London: CRC Press. 
Iflaifel, M., Lim, R. H., Ryan, K., \& Crowley, C. (2020). Resilient Health Care: A systematic review of conceptualisations, study methods and factors that develop resilience. BMC Health Services Research, 20, 324

Jobes, D. A. (2012). The Collaborative Assessment and Management of Suicidality (CAMS): An Evolving Evidence-Based Clinical Approach to Suicidal Risk. Suicide and Life-Threatening Behavior, 42(6), 640-653.

Jun, G. T., Canham, A., Noushad, F., \& Gangadharan, S. K. (2019). Safety I and Safety II for Suicide Prevention - Lessons from How Things Go Wrong and How Things Go Right in Community-Based Mental Health Services. I: Proceedings of the 20th Congress of the International Ergonomics Association (IEA 2018). Cham: Springer International Publishing.

Klein, G., Moon, B., \& Hoffman, R. R. (2006). Making sense of sensemaking 1: Alternative perspectives. IEEE Intelligent Systems, $21(4), 70-73$.

Large, M., Smith, G., Sharma, S., Nielssen, O., \& Singh, S. P. (2011). Systematic review and meta-analysis of the clinical factors associated with the suicide of psychiatric in-patients. Acta Psychiatr Scand, 124(1), 18-19.

Linehan, M. M.,Comtois, K., Murray, A., Brown, M., Gallop, R., Heard, H., ... Lindenboim, N. (2006). Two-year randomized controlled trial and follow-up of dialectical behavior therapy vs therapy by experts for suicidal behaviors and borderline personality disorder. Arch Gen Psychiatry, 63(7), 757-766.

Littlewood, D. L., Quinlivan, L., Graney, J., Appleby, L., Turnbull, P., Webb, R. T., \& Kapur, N. (2019). Learning from clinicians' views of good quality practice in mental healthcare services in the context of suicide prevention: A qualitative study. BMC Psychiatry, 19(1), 346.

Peters, M. D. J., Godfrey, C. M., Khalil, H., Mclnerney, P., Parker, D., Soares, C. B. (2015). Guidance for conducting systematic scoping reviews. International Journal of Evidence-Based Healthcare, 13(3), 141-146.

Plumb, J. (2013). Taming uncertainty? Performance, personalisation and practices of patient safety in an Australian mental health service (Doktorgradsavhandling, Faculty of Medicine). University of New South Wales: Australian Institute of Health Innovation.

Quinlivan, L., Littlewood, D. L., Webb, R. T., \& Kapur, N. (2020) Patient safety and suicide prevention in mental health services: Time for a new paradigm? J Ment Health, 29(1), 1-5.

Svensson, J. (2021). Patient Safety Strategies in Psychiatry and How They Construct the Notion of Preventable Harm: A scoping review. Journal of Patient Safety, 17(7), 473-530.

Thibaut, B., Dewa, L. H., Ramtale, S. C., D'Lima, D., Adam, S., Ashrafian, H., . . . Archer, S. (2019). Patient safety in inpatient mental health settings: A systematic review. BMJ Open, 9(12), e030230.

Turecki, G., \& Brent, D. A. (2016). Suicide and suicidal behaviour. The Lancet, 387(10024), 1227-1239.

Turenne, C. P., Gautier, L., Degroote, S., Guillard, E., Chabrol, F., \& Ridde, V. (2019). Conceptual analysis of health systems resilience: A scoping review. Social Science \& Medicine, 232, 168-180.
Turner, K., Stapelberg, N. J., Sveticic, J., \& Dekker, S. W. (2020). Inconvenient truths in suicide prevention: Why a Restorative Just Culture should be implemented alongside a Zero Suicide Framework. Aust N Z J Psychiatry, 54(6), 571-581.

Undrill, G. (2007). The risks of risk assessment. Adv Psychiatr Treat, 13(4), 291-297.

Vråle, G. B., \& Steen, E. (2005). The dynamics between structure and flexibility in constant observation of psychiatric inpatients with suicidal ideation. Journal of Psychiatric and Mental Health Nursing, 12(5), 513-518.

Waern, M., Kaiser, N., \& Renberg, E. S. (2016). Psychiatrists' experiences of suicide assessment. BMC Psychiatry, 16(1), 440.

Walby, F. A., Myhre, M. Ø., \& Kildahl, A. T. (2018). 1910 døde pasienter: Selvmord i psykisk helsevern og tverrfaglig spesialisert rusbehandling 2008 til 2015 - en nasjonal registerstudie. Oslo: Nasjonalt kartleggingssystem for selvmord i psykisk helsevern og tverrfaglig spesialisert rusbehandling, Nasjonalt senter for selvmordsforskning og forebygging, Universitetet i Oslo.

Wears, R. L., Schubert, C. C., \& Hunte, G., S. (2015) Individual-collective Trade-offs: implications for resilience. I: R. E. Wear, E. Hollnagel, \& J. Braithwaite (Red.), Resilient Health Care: Volume 2. England/Usa: Ashgate.

Wiig, S., Aase, K., Billett, S., Canfield, C., Røise, O., Njå, O., ... Macrae, C. on behalf of the RiH team (2020). Defining the boundaries and operational concepts of resilience in the resilience in healthcare research program. BMC Health Services Research, 20(1), 330

Østlie, K., Stänicke, E., \& Haavind, H. (2018). A listening perspective in psychotherapy with suicidal patients: Establishing convergence in therapists and patients private theories on suicidality and cure. Psychotherapy Research, 28(1), 150-163. 